ISSN 1112-9867

\title{
DESIGN OF CONCERT HALL IN UREMIA BASED ON NOTIFICATION TO HIDDEN ROLE OF MUSIC IN ARCHITECT
}

\author{
M. Jalilizadeh ${ }^{1}$, S. Shaghaghi ${ }^{*}$ \\ ${ }^{1}$ MSc Student of Architecture, Islamic Azad University, Shabestar Branch, Shabestar, Iran \\ ${ }^{2}$ Assistant Professor at Department of Architecture, Islamic Azad University, Shabestar Branch, \\ Shabestar, Iran
}

Published online: 15 February 2017

\begin{abstract}
The growth of sound in a concert hall is reviewed with emphasis on hearing the direct sound clearly. Architecture in its daily means provides renewed space and is replaced within a larger space and people are moving in it and in it's around. Music is purely mechanical conception, organized and deliberate scattering of sound waves in space. The aim of current research is design of concert hall based on notification to hidden role of music in architect in Uremia city. Methodology is based on librarian, descriptive-analytical method that is of applied kind. Results show that architecture and Music have practical visuals that no one can reject these characters. Also, we can presented three themes of foundation and basis physical creation, architecture and music for comparison (first: the physical essence; second: the evaluation tools for; Third: change the essence to the body with including of the idea and expand it).
\end{abstract}

Key Words: Concert Hall, Music Role, Renewed Space, Architect

\section{INTRODUCTION}

Briefly discussed is the change in architectural design of concert halls since early in the twentieth century to the present time.

doi: http://dx.doi.org/10.4314/jfas.v9i1s.731 
The growth of sound in a concert hall is reviewed with emphasis on hearing the direct sound clearly. Next, comes the desirability of hearing early lateral reflections, i.e., those from side walls (Beranek, 2004). The strength (loudness) of the orchestral sound follows with emphasis on the degree of seat upholstering and the cubic volume of the hall. It is shown that in a large number of successful concert halls the mid-frequency, fully occupied, reverberation time and the ratios of the volume to the total surface areas are nearly the same even though the volume per seat varies over a wide range. The bass index for a number of halls is discussed in relation to the weight of side walls and added sound absorbing materials. Finally, maximum and minimum seating capacities for shoebox-shaped, surround-shaped, and fan-shaped concert halls are suggested (Raggers, 2003; Janson \& et al, 1983).

All three are shoebox in shape and have lightly upholstered seats. To listeners, the sound in them is beautiful, almost luxurious; because of the rich reverberation, the quantity of early reflections that give breadth to the music, the balance of tone among the orchestral sections, and the loudness that brings listeners to their feet following a fortissimo conclusion. Also the sound is nearly uniform in about $90 \%$ of the seating areas and the players clearly hear each other, certainly in Boston and Vienna. Since the advent of the Berlin Philharmonic Hall in 1963, architects and owners have often placed beauty and novelty of architecture above acoustics. In Berlin nearly half of the audience is seated behind and to the sides of the stage. That hall has been a success even though the orchestral balance differs considerably from one seat location to another because the sounds of the various instruments are radiated in different directions, and because the listener is much closer to one part of the orchestra than to others. Nevertheless, many listeners enjoy being to the rear or sides of the orchestra so they can see the gestures and facial expressions of the conductor. Some say that at these locations they feel as though they were part of the performing group. With the piano lid up, listeners at the stage rear hear only the low notes. This is also true for soprano voices where the high tones are only projected forward (Jack \& et al, 2002).

Architecture in its daily means provides renewed space and is replaced within a larger space and people are moving in it and in it's around. Music is purely mechanical conception, organized and deliberate scattering of sound waves in space. When human moving is done in into a special space; it will be influenced the human spirit and his inner emotional space and manifested the direct reflection of sound waves on the human body. Architecture and Music have practical 
visuals that no one can reject these characters. The below picture is the largest church in the Cologne, Germany, which partly can be found in this entry and it, can be used. Image taken from the angular motion of the flat portion of the roof that if we ignore it, the graph shows that the applied method (about the peaks and mountains) can be a model for the creation of a musical work is an art of architecture.
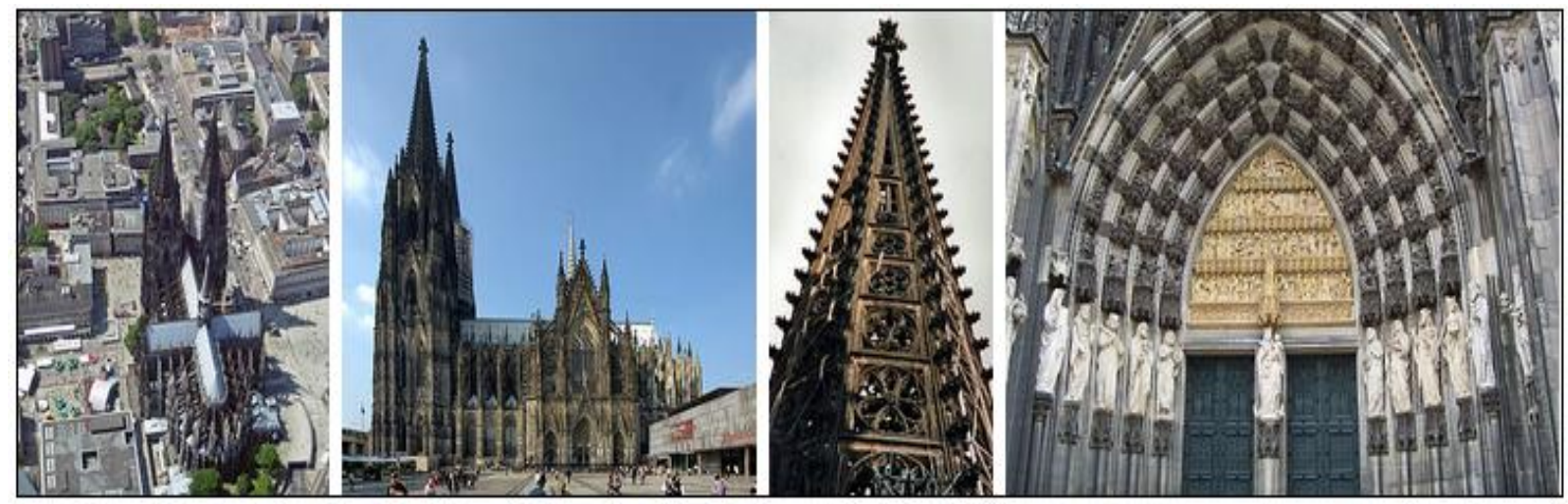

Fig.1. Cologne church a sample of music role in architecture.

\section{Background \& Examples of Concert Hall Design}

Recent designs for concert halls around the world by renowned designers have prominently featured complex curved geometry. Concert Hall designers have long employed convex surfaces in concert halls and concave surfaces in outdoor concert spaces, their potential to distribute energy where is needed has been proven by many examples1. Like any concave surface, complex double curvature surfaces need to be carefully studied and optimized to obtain desirable sound reflections and avoid sound concentrations (Méndez \& et al, 2013).

\subsection{Example 1: Walt Disney Concert Hall}

The Walt Disney Concert Hall was designed by Frank Gehry. It seats 2,265 people and serves, among other purposes, as the home of the Los Angeles Philharmonic orchestra and the Los Angeles Master Chorale. Lillian. Both Gehry's architecture and the acoustics of the concert hall, designed by Yasuhisa Toyota, have been praised, in contrast to its predecessor, the Dorothy Chandler Pavilion. As construction finished in the spring of 2003, the Philharmonic postponed its grand opening until the fall and used the summer to let the orchestra and Master Chorale adjust to the new hall. Writing about these rehearsals, Los Angeles Times music critic Mark Swed wrote the following account: When the orchestra finally got its next in Disney, it was to rehearse 
Ravel's lusciously orchestrated ballet, Daphnis and Chloé. This time, the hall miraculously came to life. Earlier, the orchestra's sound, wonderful as it was, had felt confined to the stage. Now a new sonic dimension had been added, and every square inch of air in Disney vibrated merrily. Toyota says that he had never experienced such an acoustical difference between a first and second rehearsal in any of the halls he designed in his native Japan. Salonen could hardly believe his ears. To his amazement, he discovered that there were wrong notes in the printed parts of the Ravel that sit on the players' stands. The orchestra has owned these scores for decades, but in the Chandler no conductor had ever heard the inner details well enough to notice the errors (Coates, 2005; Mark Swed, 2003; Gehry, 2003).

The organ was built by the German organ builder Caspar Glatter-Götz under the tonal direction and voicing of Manuel Rosales. It has an attached console built into the base of the instrument from which the pipes of the Positive, Great, and Swell manuals clarification needed are playable by direct mechanical, or "tracker" key action, with the rest playing by electric key action; this console somewhat resembles North-German Baroque organs, and has a closed-circuit television monitor set into the music desk. It is also equipped with a detached, movable console, which can be moved about as easily as a grand piano, and plugged in at any of four positions on the stage, this console has terraced, curved "amphitheatre"-style stop-jambs resembling those of French Romantic organs, and is built with a low profile, with the music desk entirely above the top of the console, for the sake of clear sight lines to the conductor. From the detached console, all ranks play by electric key and stop action.[citation needed]. In all, there are 72 stops, 109 ranks, and 6,125 pipes; pipes range in size from a few inches/centimeters to the longest being 32 feet (Wachtell, 1991; Valerie Scher, 2003).

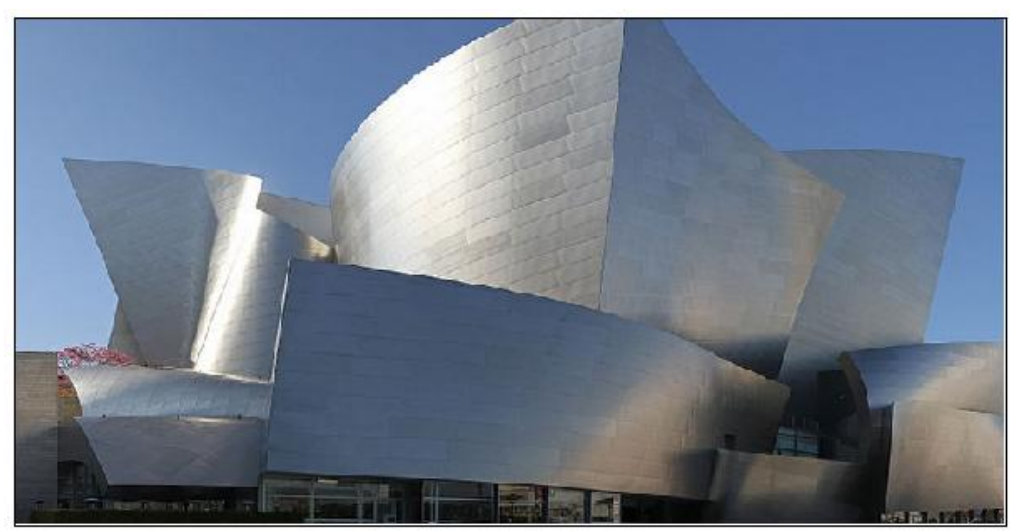

Fig.2. A view of Walt Disney Concert Hall. 


\subsection{Example 2: Cologne Cathedral}

Over the last quarter of a century, progress has accelerated in our understanding of the effects that spatial distribution of sound have on our perception. We can consider the sound propagation in a room as the change in spatial attributes of the sound field over time or as the change in time frequency response over space for a given input and output. The room response is a function of space and time, and the data can be "sliced" in many different ways for our understanding of the process. This article focuses mostly on the impulse response of a room, i.e. the response at the output due to a given input. This is an essential part of the analysis in modeling, measurement and control.

Cologne Cathedral is a Roman Catholic Church in Cologne, Germany. It is the seat of the Archbishop of Cologne and the administration of the Archdiocese of Cologne. It is a renowned monument of German Catholicism and Gothic architecture and is a World Heritage Site (Wim, 1969).It is Germany's most visited landmark, attracting an average of 20,000 people a day. Cologne's medieval builders had planned a grand structure to house the reliquary of the Three Kings and fit its role as a place of worship for the Holy Roman Emperor. Despite having been left incomplete during the medieval period, Cologne Cathedral eventually became unified as "a masterpiece of exceptional intrinsic value" and "a powerful testimony to the strength and persistence of Christian belief in medieval and modern Europe" (UNESCO, 2010).

The design of Cologne Cathedral was based quite closely on that of Amiens Cathedral in terms of ground plan, style and the width to height proportion of the central nave. The plan is in the shape of a Latin cross, as is usual with Gothic cathedrals. It has two aisles on either side, which help to support one of the very highest Gothic vaults in the world, being nearly as tall as that of the Beauvais Cathedral, much of which collapsed. Externally the outward thrust of the vault is taken up by flying buttresses in the French manner. The eastern end has a single ambulatory, the second aisle resolving into a cheviot of seven radiating chapels. Internally, the medieval choir is more varied and less mechanical in its details than the 19th century building. It presents a French style arrangement of very tall arcade, a delicate narrow triforium gallery lit by windows and with detailed tracery merging with that of the windows above. The clerestory windows are tall and retain some old figurative glass in the lower sections. The whole is united by the tall shafts that sweep unbroken from the floor to their capitals at the spring of the vault. The vault is of plain quadripartite arrangement. The choir retains a great many of its original fittings, including the 
carved stalls, which is made the more surprising by the fact that French Revolutionary troops had desecrated the building. A large stone statue of St Christopher looks down towards the place where the earlier entrance to the cathedral was, before its completion in the late 19th century. The nave has many 19th century stained glass windows. A set of five on the south side is called the Bayernfenster, and were a gift from Ludwig I of Bavaria, and strongly represent the painterly German style of that date. Externally, particularly from a distance, the building is dominated by its huge spires, which are entirely Germanic in character, being openwork like those of Ulm, Vienna and Regensburg Cathedrals (Banister, 2010).

Table 1. Dimensions of Cologne Cathedral

\begin{tabular}{|c|c|}
\hline External length & $144.58 \mathrm{~m}(474.3 \mathrm{ft})$ \\
\hline External width & $86.25 \mathrm{~m}(283.0 \mathrm{ft})$ \\
\hline Width of west façade & $61.54 \mathrm{~m}(201.9 \mathrm{ft})$ \\
\hline Width of transept façade & $39.95 \mathrm{~m}(131.1 \mathrm{ft})$ \\
\hline $\begin{array}{l}\text { Width of nave (with aisles, } \\
\text { interior) }\end{array}$ & $45.19 \mathrm{~m}(148.3 \mathrm{ft})$ \\
\hline Height of southern tower & $157.31 \mathrm{~m}(516.1 \mathrm{ft})$ \\
\hline Height of northern tower & $157.38 \mathrm{~m}(516.3 \mathrm{ft})$ \\
\hline Height of ridge turret & $109.00 \mathrm{~m}(357.61 \mathrm{ft})$ \\
\hline Height of transept façades & $69.95 \mathrm{~m}(229.5 \mathrm{ft})$ \\
\hline Height of roof ridge & $61.10 \mathrm{~m}(200.5 \mathrm{ft})$ \\
\hline Inner height of nave & $43.35 \mathrm{~m}(142.2 \mathrm{ft})$ \\
\hline Building area & $7,914 \mathrm{~m}^{2}(85,185.59 \mathrm{sq} \mathrm{ft})$ \\
\hline Window surface area & $10,000 \mathrm{~m}^{2}(107,639.10 \mathrm{sq} \mathrm{ft})$ \\
\hline Roof surface area & $12,000 \mathrm{~m}^{2}(129,166.93 \mathrm{sq} \mathrm{ft})$ \\
\hline $\begin{array}{lll}\text { Gross volume } & \text { without } \\
\text { buttresses } & & \end{array}$ & $407,000 \mathrm{~m}^{3}(14,400,000 \mathrm{cu} \mathrm{ft})$ \\
\hline
\end{tabular}

Source: Monate, 2013. 


\section{Case study Region and Material}

Uremia is the capital of West Azerbaijan Province, Iran. Uremia is situated at an altitude of 1,330 m above sea level. It is located along the City River on the Uremia Plain. Lake Uremia lies to the east of the city with the mountainous Turkish border to the west (http://en.wikipedia.org/, 2014). Uremia is the $10^{\text {th }}$ most populated city in Iran. At the 2012 census, its population was 1,265,721 with 700,000 households. The city's inhabitants are predominantly Azeris who live alongside minorities of Kurds, Assyrians, Jews and Armenians. The city is the trade center for a fertile agricultural region where fruit (especially apple and grape) and tobacco are grown. An important town by the 9th century, Urmia was seized by the Seljuk Turks (1184), and later occupied a number of times by the Ottoman Turks (Census of the Islamic Republic of Iran, 2006).

In order to, present research has a descriptive-analytical method that is of applied kind. Their theory foundation is based on attribution and desk studies and field visits of related researches. Information has been collected on Design of Concert Hall in Uremia with point on people need spaces in Uremia city characteristics (open \& closed questionnaire's) along with interviews. This information is collected in two documents and field ways.

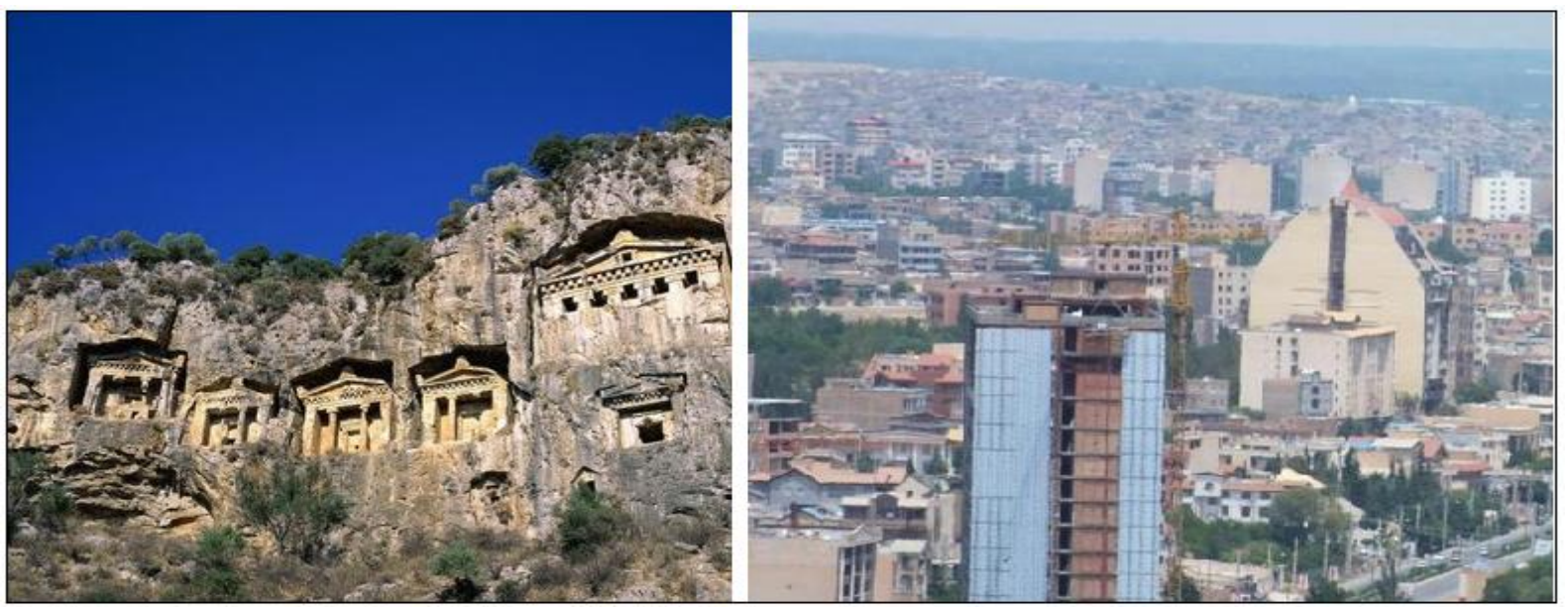

Fig.3. A view of Case study Region.

\section{RESULTS \& CONCLUSION}

We have followed three themes of foundation and basis physical creation, architecture and music for comparison.

- first: the physical essence; 
- second: the evaluation tools for;

- Third: change the essence to the body with including of the idea and expand it.

\subsection{Sound height and the dimensions of visual symptoms}

In the architecture world, the dimensions as one of the quantity features are equal with sound height in music. In each architecture building, visual symptoms with different dimensions are located in the defined places.

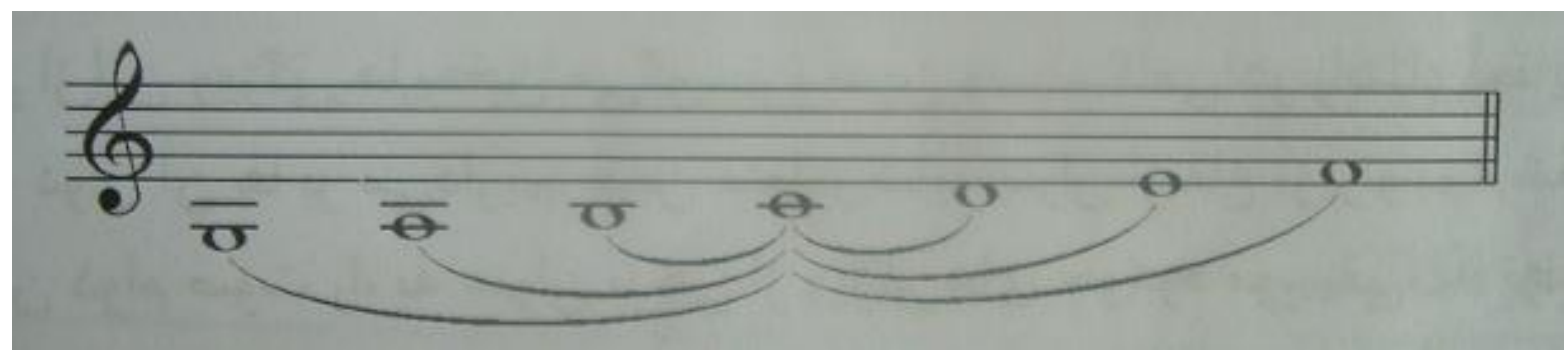

Fig.4. Tonic Net- two mazhor step of attraction sound center

Every architect for creation his sign use of special aspects to creation of visual symptoms. These signs are measured in human basis. Because the audiences of architecture spaces are humans and therefore all aspects of visual symptoms relative to their body size measures. According to the definition of central sound in music, we can know the role of human dimensions in visual signals as Tonic role in the sounds. Architecture in its daily meaning while it led to renewal the spaces, it is replaced within a larger space. In order to, we can know the pupil of the eye and eardrum as openings that related the inner and outer human world to each other. However it is based on experience that following of certain roles that explain the technical precision - physical condition of success in the creation of melodies and generally pleasant and beautiful music is known in academia - since thousands of years ago - to be trained.

\subsection{Sound intensity and distance visual symptoms}

One of the characteristics of sound is it's aggressively that it is used as a means to giving dimensions to voice by composers. In the creation of music can be woke the special feelings in the listener by sudden and gradual changes in sound intensity. For example, a gradual increase in sound intensity, especially when noise is associated with increased altitude can trigger a sense of 
excitement in the listener's mind and to reduce the gap where the audience and the musical sound, Gates asserted.

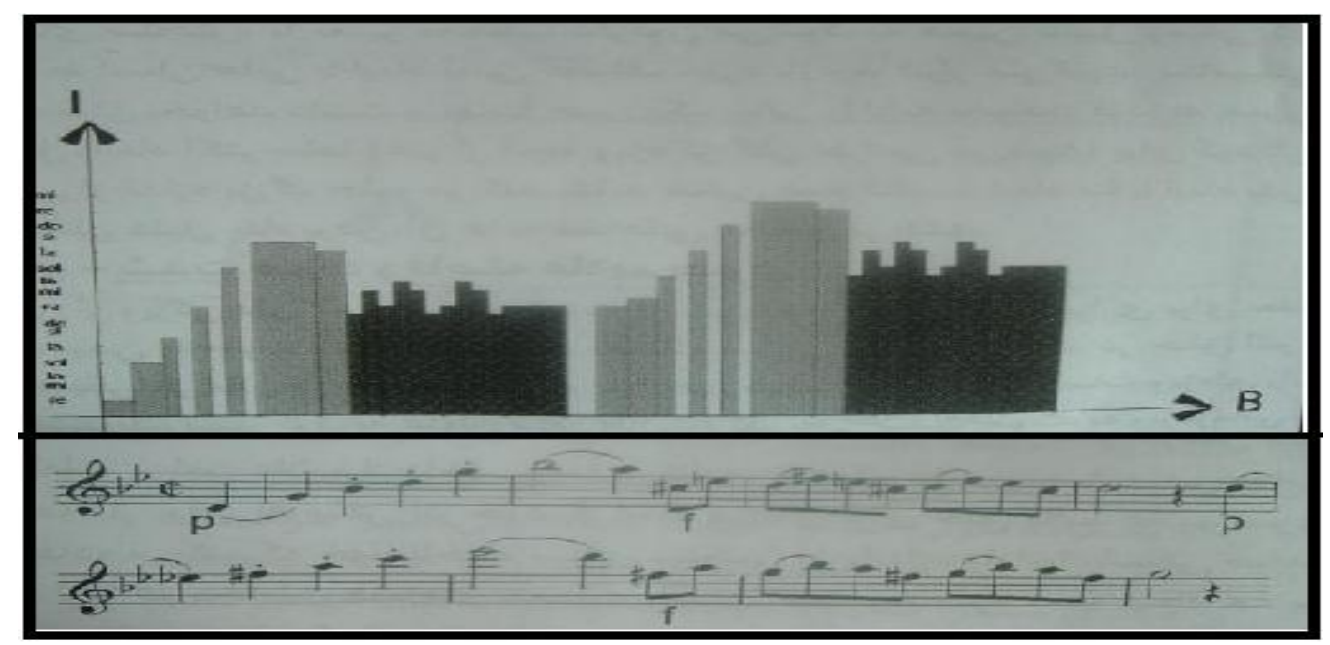

Fig. 5. The variation of intensity of sound - dynamic step

\subsection{The Essence of qualitative features}

Voice has a feature that cannot be measured but it is recognizable and we can mention it as voice quality features. It is nothing but a stamp or type sound, color or sound generating device that communicates directly with the apparatus. Apparatus have the ability of special sentiment in the audience. Visual symptoms in architecture have two qualitatively features that include of color and texture of the visual symptoms which they have direct relation with generating tools of matter visual sings. Any substance has the capable of stimulating the special feeling audience. For example, concrete awaken the sense of violence and tenacity in human, while wood gives a sense of warmth and comfort to people. Similarly, strong colors are exciting and provocative poses and gentle, relaxing and soothing colors. Qualitative characteristics of essence in music and architecture are already fixed by the artist.

\subsection{Convert substance to the body including ideas and it's expand}

In the architecture figure is the smallest unit includes the concept and it is play a role such motifs in music. The form refers to a set of visual signs that are recognizable identity and to contribute to the understanding of geometry. Forms can also change the time format; they can be duplicated and expanded or reduced. 


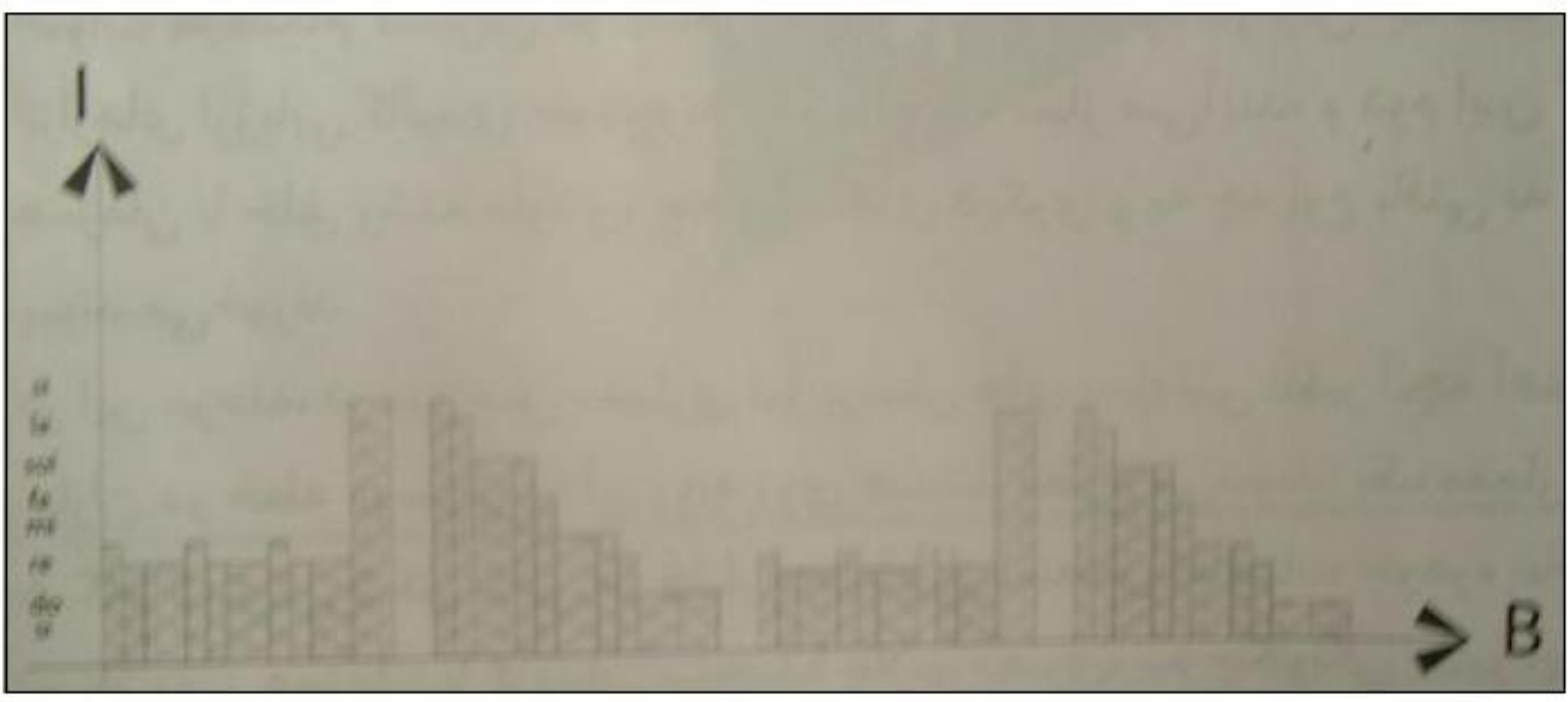

Fig. 6. Formation and expansion of the motif

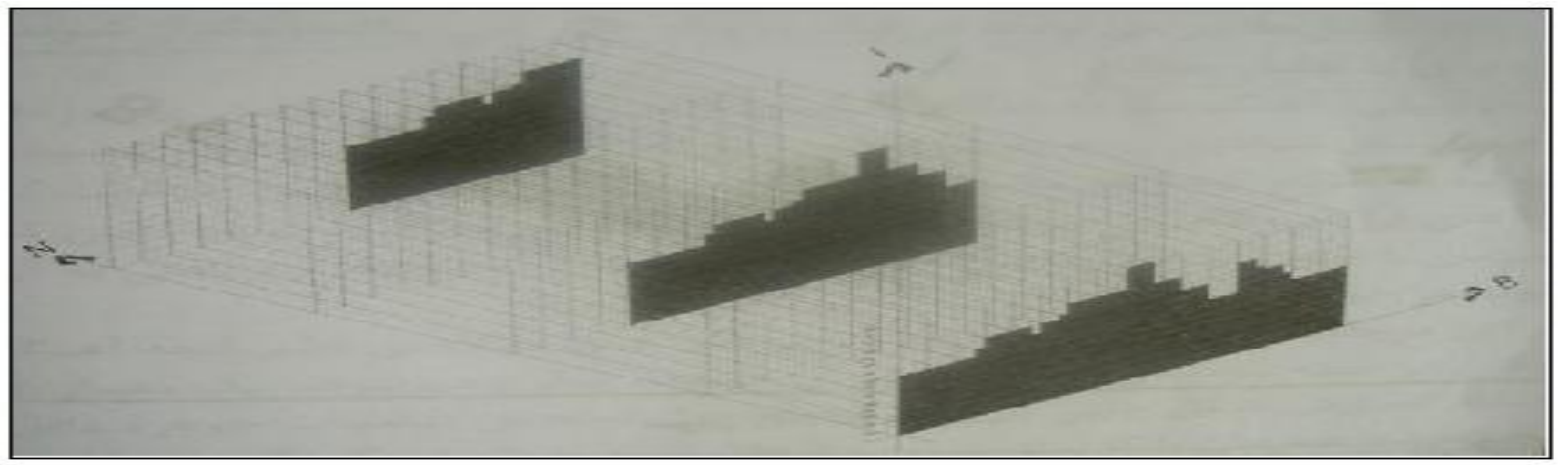

Fig. 7. Polyphonic texture chart

All three are shoebox in shape and have lightly upholstered seats. To listeners, the sound in them is beautiful, almost luxurious; because of the rich reverberation, the quantity of early reflections that give breadth to the music, the balance of tone among the orchestral sections, and the loudness that brings listeners to their feet following a fortissimo conclusion. Also the sound is nearly uniform in about $90 \%$ of the seating areas and the players clearly hear each other, certainly in Boston and Vienna. Since the advent of the Berlin Philharmonic Hall in 1963, architects and owners have often placed beauty and novelty of architecture above acoustics. In Berlin nearly half of the audience is seated behind and to the sides of the stage. That hall has been a success even though the orchestral balance differs considerably from one seat location to another because the sounds of the various instruments are radiated in different directions, and because the listener is much closer to one part of the orchestra than to others. 
Early reflections in concert spaces have been determined to be crucial to the overall acoustic quality by many researchers in the past, and the characteristics of early sound are very dependent on the room shape, while the late sound energy is more dependent on average room absorption. Any substance has the capable of stimulating the special feeling audience. For example, concrete awaken the sense of violence and tenacity in human, while wood gives a sense of warmth and comfort to people. Similarly, strong colors are exciting and provocative poses and gentle, relaxing and soothing colors. Qualitative characteristics of essence in music and architecture are already fixed by the artist. According to above mentioned, forms can also change the time format; they can be duplicated and expanded or reduced.

\section{REFERENCES}

Banister, M. 2010. The Economic Approach to Social Capital." Working Paper No. 7728, National Bureau of Economic Research, Cambridge, MA.

Beranek, H. 2004. How They Sound - Concert and Opera Halls Acoustical Society of America, Woodbury, New York.

Coates, R. 2005. The subjective effects of first reflections in concert halls-The need for lateral reflections, Journal of Sound and Vibration, Volume 15, Issue 4, 22 April 1971, Pages 475-494. Gehery, C. 2003. orsamkeit von Sprache. Acustica 1.

Iranian census center, 2006.

Janson, M. Naseri, J. Badfv, R. 2002. section in concert halls. Sound, Vib. 5, pps $100-112$, 1967.

Mark, S. 2003. An acoustics measurement program for evaluating auditoriums based on the early/late sound energy ratio. J. Acoust. Soc. Am. 96, 2251.

Mendez, T. Sassano, M. Astolfi, A. Harten, A. 2013. Interactive Design Methods for Complex Curved Reflectors in Concert Halls. International Symposium on Room Acoustics.

Raggers, B. 2003. General Metatheory of Auditory Localisation Preprint 3306 of the 92nd AES Convention, Vienna.

Valerire Scher, J. 2003. Mean-free-paths in concert halls and chamber music halls and the Sabine-Eyring equations for predicting their reverberation times," ICA 2013 Congress in Montreal, June 6-7. 
Watchtell, C. 1991. objective measures for concert auditoria, ISO 3382, to give reliable results. Acoust. Sci. \& Tech. 26, 2

Wim, J. 1969. Values of $\mathrm{G}$ by the reverberation chamber method are about $1.2 \mathrm{~dB}$ higher than those by the other method. It has been shown that the former yields the correct results.

How to cite this article:

Jalilizadeh M, Shaghaghi S. Design of concert hall in uremia based on notification to hidden role of music in architect. J. Fundam. Appl. Sci., 2017, 9(1S), 777-788. 